\title{
Występowanie rzadkich gatunków chrząszczy saproksylicznych w lasach gospodarczych na przykładzie Puszczy Knyszyńskiej (RDLP w Białymstoku)
}

\author{
ADAM KWIATKOWSKI i DAWID MARCZAK
}

\begin{abstract}
KwiatKowski, A. AND MarcZaK, D. 2020. Occurrence of rare saproxylic beetle species in timberland of the Knyszyńska Forest (Regional Directorate of State Forests in Białystok, Poland). Fragmenta Floristica et Geobotanica Polonica 27(1): 55-71. Kraków. e-ISSN 2449-8890, ISSN 1640-629X.

ABSTRACT: Cucujus cinnaberinus and Boros schneideri are saproxylic insects, an important group of organisms linked with deadwood. Both are rare protected species, relicts of primeval forest. Observations of both species in the Knyszyńska Forest in 2018 and 2019 showed that they occur in forests protected under different conservation regimes and in sustainably managed forest. Specimens of $C$. cinnaberinus were present on many snags of various tree species in nature reserves and also in sustainably managed forest, where the insects were found on single dead trees, within retention patches, and in representative sample areas (RSAs). Specimens of B. schneideri observed in sustainably managed forest were found in reference forests, retention patches and also on single Scots pine snags. These observations from the Knyszyńska Forest suggest that it is possible to balance economic imperatives with the need to protect rare species in sustainably managed forest.
\end{abstract}

KeY wORDS: Boros schneideri, Cucujus cinnaberinus, forest management, Knyszyńska Forest, primeval forest relict, saproxylic beetles

A. Kwiatkowski (autor korespondencyjny), Instytut Nauk Leśnych, Wydziat Budownictwa i Nauk o Środowisku, Politechnika Biatostocka, ul. Wiejska 45A, 15-351 Biatystok, Polska; Regionalna Dyrekcja Lasów Państwowych w Białymstoku, ul. Lipowa 51, 15-424 Biatystok, Polska; e-mail: akfiatek1@wp.pl;

D. Marczak, Wydziat Inżynierii i Zarzqdzania, Wyższa Szkoła Ekologii i Zarzqdzania w Warszawie, ul. Olszewska 12,00-792 Warszawa,Polska; e-mail: dawid.marczak@gmail.com

\section{WSTĘP}

Saproksyliczne owady to gatunki, których środowiskiem życia w poszczególnych fazach rozwoju są zamarłe drzewa w różnych stadiach rozkładu. Są to zarówno martwe drzewa, jak i martwice czy próchnowiska na żywych drzewach (GUTOwSKI 2006). W omawianych obserwacjach skupiono się na dwóch rzadkich gatunkach chrząszczy saproksylicznych: Cucujus cinnaberinus Scop. (zgniotku cynobrowym) oraz Boros schneideri Panz. (ponurku Schneidera). Oba gatunki objęte są ochroną na mocy rozporządzenia Ministra 
Środowiska o ochronie gatunkowej zwierząt (RozPORZĄDZENIE 2016) oraz umieszczone zostały w załączniku II dyrektywy Rady 92/43/EWG z dnia 21 maja 1992 r. w sprawie ochrony siedlisk przyrodniczych oraz dzikiej fauny i flory (DYREKTYWA RADY 1992). Oba gatunki są wpisane na Europejską ,czerwoną listę” chrząszczy saproksylicznych (NIETO \& ALEKSANDER 2010) - Boros schneideri z kategorią VU (gatunek narażony), a C. cinnaberinus z kategorią NT (bliski zagrożenia), jest również uznany za relikt lasów pierwotnych (ECKELT i in. 2017).

Cucujus cinnaberinus to gatunek chrząszcza (Coleoptera) z rodziny Cucujidae (zgniotkowatych), wskazywany w literaturze jako jeden z rzadziej występujących w Polsce owadów saproksylicznych (MARCZAK 2016). Przez niektórych autorów uznawany jest za relikt lasów pierwotnych (KuBisz 2004; BuchHOLz 2012), ale nie ma wśród naukowców jednomyślności w tej kwestii. Coraz częściej w literaturze pojawiają się wątpliwości odnośnie jego reliktowego charakteru (SMOLIS i in. 2012). EcKelt i in. (2017) nie wskazują tego gatunku jako reliktu lasów pierwotnych. W ostatnich latach odnotowywane jest jego występowanie w ekosystemach zniekształconych, m.in. na plantacjach topolowych (HORAK i in. 2010), czy w innych siedliskach leśnych i zaroślowych o różnym stopniu przekształcenia przez człowieka (TrZeciak 2011; MiŁKowski 2012; PrZewoźny 2014; Dorda \& FiedoR 2019). Poszerza się tym samym wiedza o rozmieszczeniu gatunku i jego preferencjach siedliskowych. Wydaje się, że jest to owad dość plastyczny pod względem wyboru gatunków drzew odpowiednich do zasiedlenia. Notowany jest zarówno na drzewach iglastych, jak i liściastych, w szczególności: Populus tremula, Salix sp., Quercus sp., Alnus glutinosa, Fraxinus excelsior, Pinus sylvestris, Abies alba, Carpinus betulus, Picea abies, Acer platanoides czy Ulmus sp. (KuBISz 2004; BuchHolz 2012; Smolis i in. 2012; PlewA i in. 2014; MARCZAK 2016; JAWORSKI i in. 2019). Odnotowano również występowanie larw C. cinnaberinus w takich gatunkach, jak Robinia pseudoacacia oraz Padus avium (BuchHolz i in. 2013).

Drugim rzadkim gatunkiem chrząszcza, poszukiwanym w Puszczy Knyszyńskiej, był Boros schneideri, należący do rodziny Boridae (ponurkowatych). Jest to gatunek uznawany za relikt lasów pierwotnych (ECKELT i in. 2017). Zasiedla przede wszystkim Pinus sylvestris. Poza tym jest czasem spotykany na innych gatunkach drzew, takich jak Picea abies, Abies alba, Alnus glutinosa, Quercus sp., Betula sp. czy Fraxinus excelsior (Gutowski i in. 2014; GUTOWSKI 2015; JAWORSKI i in. 2019).

Oba gatunki rozwijają się na martwych drzewach, będących w początkowej fazie rozkładu. Wymagają więc do zasiedlenia drzew z rozkładającym się łykiem i lekko odstająca korą. W Puszczy Knyszyńskiej Cucujus cinnaberinus do tej pory notowany był z nielicznych stanowisk w rezerwatach przyrody (BuchHolz 2012) oraz z nadleśnictwa Waliły (PlewA $\mathrm{i}$ in. 2014). Na temat występowania na badanym terenie drugiego z gatunków - Boros schneideri - brak jest w literaturze doniesień o jego stwierdzeniach w tym kompleksie leśnym. Najbliższe opisane stanowiska znane są z Puszczy Białowieskiej oraz nieliczne z Puszczy Augustowskiej (GuTOwski 2015).

Celem przeprowadzonych badań było wstępne rozpoznanie występowania Cucujus cinnaberinus i Boros schneideri oraz innych rzadkich gatunków saproksylicznych chrząszczy w Puszczy Knyszyńskiej, w tym również w drzewostanach zagospodarowanych. 


\section{TEREN BADAŃ}

Puszcza Knyszyńska to kompleks leśny, położony w północno-wschodniej Polsce, otaczający od północy i wschodu Białystok. Jest to jeden z większych kompleksów leśnych w kraju, rozciagga się na powierzchni około 114 tys. ha (SокOŁOwSKi 2006). Lasy Puszczy Knyszyńskiej charakteryzują się dużym zróżnicowaniem, zarówno siedliskowym, jak i gatunkowym. O wyjątkowych walorach przyrodniczych Puszczy przesądza przede wszystkim mozaika różnorodnych siedlisk. Dominują siedliska borowe, stanowiące 66,8\% siedlisk leśnych, udział siedlisk lasowych wynosi 33,2\%. Siedliska wilgotne i bagienne, zarówno borowe jak i lasowe, stanowią 11,1\% (SoKOŁOWSKI 2006).

Do osobliwości Puszczy Knyszyńskiej należą liczne punktowe wypływy wód podziemnych, których jest tu 430 (GóRNIAK \& JEKATERYNCZUK-RUDCZYK 1995). Źródła stanowią początek leśnych potoków, które istotnie zasilają w wodę większe cieki oraz tworzą cenne siedliska przyrodnicze, stanowiące ważny element urozmaicający krajobraz leśny Puszczy.

Lasy Puszczy Knyszyńskiej są zarządzane przez siedem nadleśnictw: Czarna Białostocka, Dojlidy, Knyszyn, Krynki, Supraśl, Waliły i Żednia. Prowadzona jest tam, w oparciu o plany urządzenia lasu, wielofunkcyjna gospodarka leśna. Mimo prowadzonej od wieków gospodarki leśnej, wiele fragmentów Puszczy zachowało naturalny charakter, co jest szczególnie widoczne na terenach wilgotnych i bagiennych, a więc najbardziej niedostępnych (SoKOŁOWSKI 1981). Puszcza objęta jest różnymi formami ochrony przyrody. Najcenniejsze fragmenty Puszczy chronione są w 23 rezerwatach przyrody (SoKOŁOwSKI 2006). Na przeważającej części utworzono Park Krajobrazowy Puszczy Knyszyńskiej im. prof. Witolda Sławińskiego. Całość obszaru Puszczy objęta jest ochroną w ramach programu Natura 2000, zgodnie z którym wyznaczono dwa, w znacznej części pokrywające się, obszary: PLB200003 Puszcza Knyszyńska, powołany na mocy dyrektywy 79/409/EWG z 2 kwietnia 1979 r. o ochronie dziko żyjących ptaków (DYREKTYwa RADY 1979) oraz PLH200006 Ostoja Knyszyńska, powołany na mocy dyrektywy 92/43/EWG z dnia 21 maja 1992 r. w sprawie ochrony siedlisk przyrodniczych oraz dzikiej fauny i flory (DYREKTYwA RADY 1992).

Puszcza Knyszyńska jest kompleksem leśnym, będącym w zdecydowanej większości w zarządzie Lasów Państwowych i pozostającym w użytkowaniu gospodarczym. Niewielkie obszary leśne są własnością osób prywatnych. Kluczowym elementem ekosystemu leśnego, z punktu widzenia ochrony bioróżnorodności, jest obecność w nim zamarłych drzew i rozkładającego się drewna. W planach urządzenia lasu podano przeciętną zasobność tego substratu w poszczególnych obrębach leśnych, obliczoną w trakcie prac taksacyjnych. Z analizy tych dokumentów wynika, że w Puszczy Knyszyńskiej zasobność zamarłych drzew w poszczególnych obrębach leśnych zawiera się w przedziale od 4,76 m²/ha do 17,77 $\mathrm{m}^{3} / \mathrm{ha}$. $\mathrm{Z}$ uwagi na różne okresy pomiarów wykonywanych podczas prac nad planami urządzenia lasu dla poszczególnych nadleśnictw, nie można zgeneralizować tych danych dla całej Puszczy. W tabeli 1 podano średnie wartości zasobności martwych drzew w puszczańskich obrębach poszczególnych nadleśnictw.

Należy zaznaczyć, że zasobności obliczone dla Puszczy Knyszyńskiej znacznie odbiegają od średniej wartości dla całego kraju, wynoszącej $5,5 \mathrm{~m}^{3} / \mathrm{ha}$ (BIURo URZĄDZANIA LASU I GeODEZJI LeŚNEJ 2015). Na taki wynik wpływ ma sposób zagospodarowania Puszczy, 
Tabela 1. Zasobność martwych drzew na obszarze Puszczy Knyszyńskiej w obrębach leśnych Planu Urządzania Lasu (PUL)

Table 1. Volume of deadwood in the Knyszyńska Forest (according to Forest Management Plans)

\begin{tabular}{l|c|c|c}
\hline \hline $\begin{array}{l}\text { Nadleśnictwo } \\
\text { Forest district) }\end{array}$ & $\begin{array}{c}\text { Poczatkowy rok PUL } \\
\text { (Starting year of FMP) }\end{array}$ & $\begin{array}{c}\text { Obręb } \\
\text { (Subdistrict) }\end{array}$ & $\begin{array}{c}\text { (Zasobność) } \\
\text { (Volume) } \\
{\left[\mathrm{m}^{3} / \mathrm{ha}\right]}\end{array}$ \\
\hline Czarna Białostocka & 2016 & $\begin{array}{c}\text { Czarna Białostocka } \\
\text { Złota Wieś }\end{array}$ & 8,16 \\
\hline Dojlidy & 2017 & Katrynka & 10,76 \\
\hline Supraśl & 2016 & Sokółka & 12,36 \\
\hline Knyszyn & 2018 & Supraśl & 15,45 \\
\hline Krynki & 2018 & Knyszyn & 10,90 \\
\hline Waliły & 2018 & Krynki & 10,71 \\
\hline & & Waliły & 12,60 \\
Żednia & 2019 & Hieronimowo & 6,46 \\
& & Michałowo & 6,23 \\
& & Zajma & 17,77 \\
\hline
\end{tabular}

a w szczególności obecność 23 rezerwatów przyrody oraz znaczna ilość stref ochronnych wokół gniazd ptaków. Istotnym czynnikiem jest stosowanie się do regulacji dotyczących ochrony różnorodności w lasach, w ramach prowadzonej gospodarki leśnej, takich jak InStRUKCJA OChrony LASU (2012) oraz Rozporządzenie Ministra Środowiska z dnia 18.12.2017 r. w sprawie wymagań dobrej praktyki w zakresie gospodarki leśnej (ROZPORZĄDZENIE 2017). Na tej podstawie nadleśnictwa podejmują szereg działań, które zapewniają obecność zamarłych drzew w lesie. Ważnym elementem jest pozostawianie drzew biocenotycznych oraz pojedynczych martwych drzew, stanowiących posusz jałowy. Zwiększaniu ilości dogodnych do rozwoju saproksylobiontów siedlisk bez wątpienia sprzyja pozostawianie kęp starodrzewu na powierzchniach objętych rębniami, w których wszystkie drzewa pozostają do naturalnej śmierci i rozkładu. Dodatkowo znaczną część w Puszczy stanowią tereny trudno dostępne, takie jak bagna i podmokłe doliny rzek (SoKOŁOWSKI 2006). Obszary te w szczególności są wyznaczane przez nadleśnictwa jako obszary referencyjne, w których nie prowadzi się pozyskania drewna. Rozkład przestrzenny ilości zamarłych drzew i leżaniny nie jest równomierny w kompleksie Puszczy. $\mathrm{Z}$ uwagi na różne warunki siedliskowe, drzewostanowe oraz formę zarządzania, mamy do czynienia z obszarami o większej (rezerwat przyrody, lasy referencyjne) lub mniejszej (las gospodarczy) zasobności w martwe drzewa.

\section{METODY BADAŃ}

W latach 2018 i 2019 w lasach Puszczy Knyszyńskiej prowadzono obserwacje pod kątem występowania rzadkich owadów saproksylicznych, w szczególności Cucujus cinnaberinus i Boros schneideri. Obserwacje prowadzono na napotkanych w lesie martwych drzewach, które mogły być potencjalnymi siedliskami badanych gatunków. Ze względu na duże spektrum drzew zasiedlanych przez oba gatunki, poszukiwania prowadzono na każdym napotkanym drzewie iglastym lub liściastym, zamarłym lub obumierającym. Obserwacjom poddawano drzewa występujące w litym drzewostanie, w kępach ekologicznych, na zrębach 
i uprawach. W trakcie poszukiwań na równi traktowano drzewostany gospodarcze, jak i te poddane różnym reżimom ochronnym.

Napotkanie martwe drzewa, zarówno leżące jak i stojące, były sprawdzane poprzez delikatne podważanie kory i lustrację przestrzeni pod korą. Czynność tę wykonywano w taki sposób, żeby nie oderwać trwale kory. Po stwierdzeniu przynajmniej jednego osobnika (zarówno larwy jak i imagines) przerywano poszukiwania. Przeprowadzono również poszukiwania osobników dorosłych Cucujus cinnaberinus w okresie rójki na korze martwych drzew, w porze nocnej, z użyciem latarki. Poszukiwania prowadzono według metodyki opisanej w pracach BuchHolza (2012), GutowsKIEGo (2015) i MARCZAKA (2016). Przy okazji notowano również występowanie innych rzadkich gatunków chrząszczy saproksylicznych.

Na każdym stanowisku notowano gatunek drzewa na jakim wystąpiły owady, typ siedliskowy lasu, pozycję drzewa (leżące, stojące) oraz sposób zarządzania w danym fragmencie lasu (las gospodarczy, rezerwat przyrody, strefa wokół gniazd ptaków, las referencyjny). Ważną informacją był rodzaj siedliska, w którym stwierdzano owady, a więc czy stanowisko jest w zwartym drzewostanie, czy na zrębie (kępa ekologiczna, pojedyncze drzewo na zrębie). Odnotowano również pochodzenie drzewostanu, szczególnie w przypadku zalesień porolnych. Zebrane dane posłużyły do rozpoznania występowania szczególnie dwóch gatunków - Cucujus cinnaberinus oraz Boros schneideri, objętych ochroną w ramach sieci Natura 2000 na obszarze Puszczy Knyszyńskiej. Takie wstępne rozpoznanie pozwoli w przyszłości zaplanować szersze badania występowania i preferencji siedliskowych obu gatunków w analizowanym kompleksie leśnym.

\section{WYNIKI}

Podczas prowadzonych obserwacji w Puszczy Knyszyńskiej stwierdzono obecność Cucujus cinnaberinus na 74 drzewach. Na kilku gatunkach drzew obserwowano zarówno owady doskonałe (imagines), jak również larwy. Chrząszcz ten, na ogół, był stwierdzany w większej liczbie osobników na jednym drzewie. Zdarzało się, że pod niewielkim płatem kory spotykano od kilku do kilkunastu larw lub imagines. W jednym przypadku zaobserwowano 31 larw. Najczęściej osobniki tego gatunku spotykano na Pinus sylvestris (52 drzewa), następnie na Populus tremula (10 drzew), Quercus sp. (6 drzew), Acer platanoides (2 drzewa) oraz po jednym stwierdzeniu na Alnus glutinosa, Fraxinus excelsior, Betula pendula i Ulmus sp. Nie stwierdzono żadnego przypadku zasiedlenia na Picea abies, pomimo że gatunek ten nie był pomijany w poszukiwaniach. Zebrane dane nie dają możliwości przeprowadzenia analizy statystycznej dotyczącej selektywności wyboru drzew przez C. cinnaberinus, a duży udział zasiedlonych $P$. sylvestris może wynikać z dominacji tego gatunku w Puszczy. Udział poszczególnych gatunków drzew zasiedlonych przez badany gatunek przedstawia rycina 1 .

Zasiedlone drzewa znajdowały się w następujących typach siedliskowych lasu (zgodnie z opisami taksacyjnymi drzewostanów): las mieszany świeży, las świeży, bór mieszany świeży, las wilgotny, ols oraz las mieszany wilgotny, bór mieszany bagienny i bór świeży (Ryc. 2).

Owady znajdowano przede wszystkim w drzewostanie, ale również na zrębach, gdzie pozostawiono kępy ekologiczne lub pojedyncze drzewa. Najwięcej stwierdzeń odnotowano w drzewostanie, gdzie było zasiedlonych 60 drzew (81\%), natomiast na zrębach i uprawach Cucujus cinnaberinus zasiedlał 14 drzew (19\%). Pod względem sposobu zagospodarowania lasu, gatunek był stwierdzany w drzewostanach objętych różnymi formami ochrony przyrody, w szczególności w rezerwatach przyrody, lasach gdzie powołano strefy ochronne wokół gniazd ptaków czy w drzewostanach referencyjnych. Natomiast najwięcej stwierdzeń dotyczyło drzewostanów gospodarczych nieobjętych szczególnymi reżimami ochronnymi, 


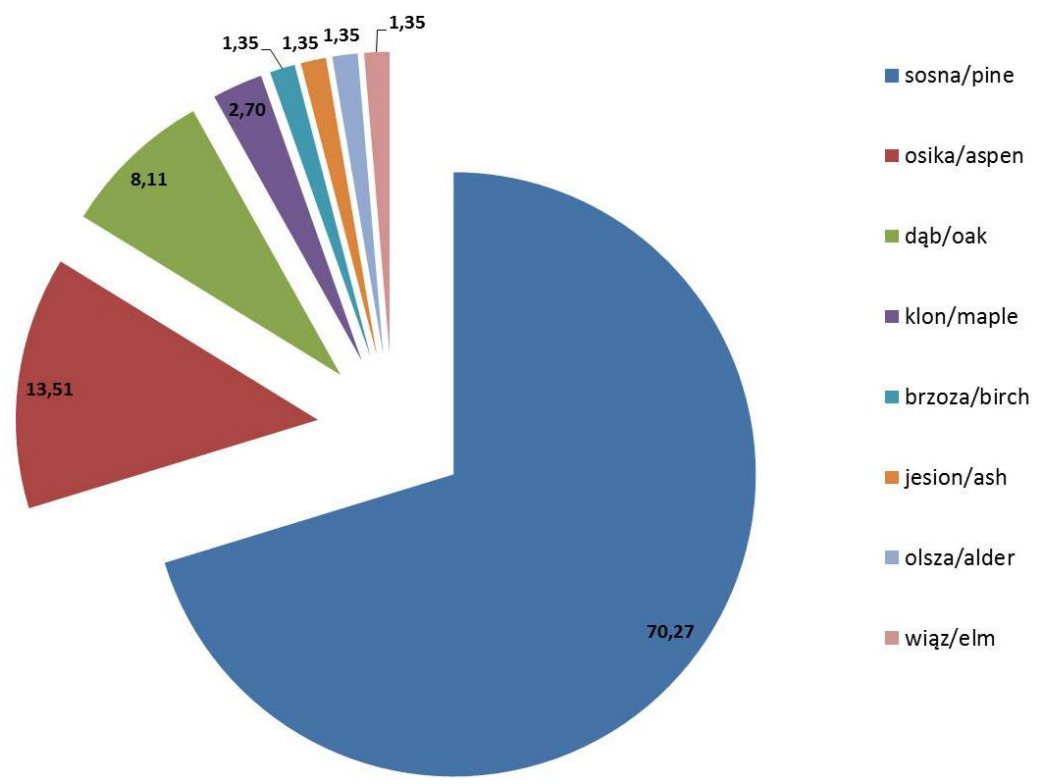

Ryc. 1. Udział drzew, na których obserwowano Cucujus cinnaberinus w Puszczy Knyszyńskiej

Fig. 1. Percentage of trees on which Cucujus cinnaberinus was observed in the Knyszyńska Forest

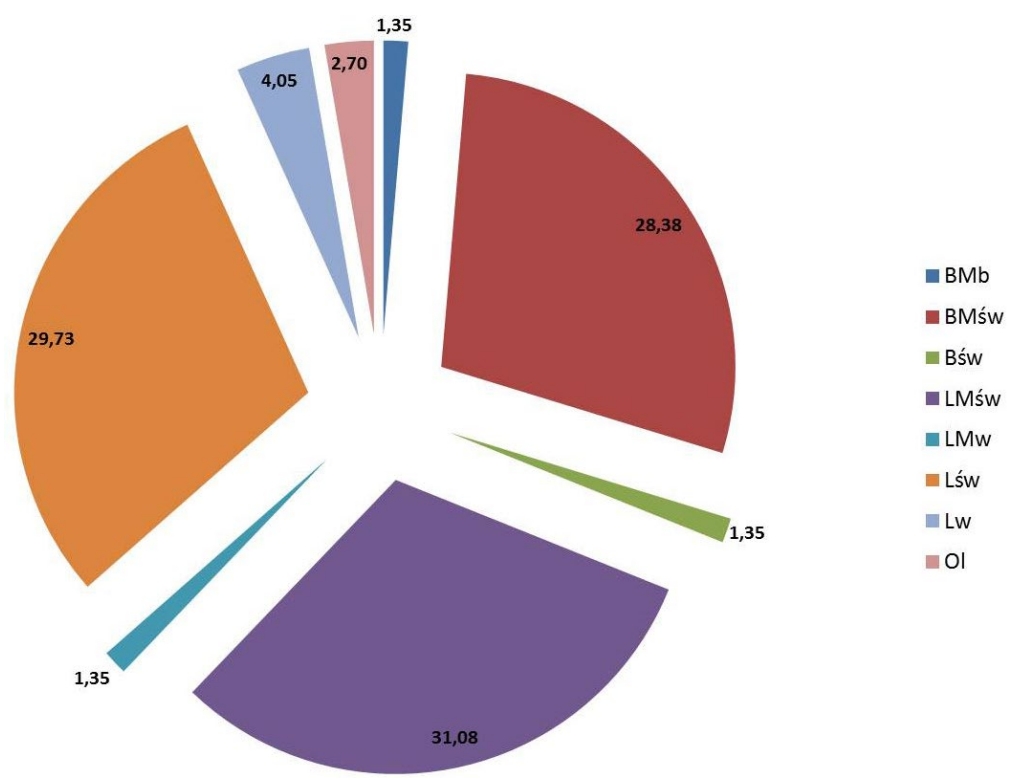

Ryc. 2. Udział typów siedliskowych lasu, w których obserwowano Cucujus cinnaberinus w Puszczy Knyszyńskiej. BMb - bór mieszany bagienny, BMśw - bór mieszany świeży, Bśw - bór świeży, LMśw - las mieszany świeży, LMw - las mieszany wilgotny, Lśw - las świeży, Lw - las wilgotny, Ol - ols

Fig. 2. Percentage of different types of forest in which Cucujus cinnaberinus was observed in the Knyszyńska Forest. $\mathrm{BMb}$ - mixed coniferous bog forest, BMśw - fresh mixed coniferous forest, Bśw - fresh coniferous forest, LMśw - fresh mixed broadleaved forest, $\mathrm{LMw}$ - moist mixed broadleaved forest, Lśw - fresh broadleaved forest, $\mathrm{Lw}$ - moist broadleaved forest, $\mathrm{Ol}$ - alder forest 


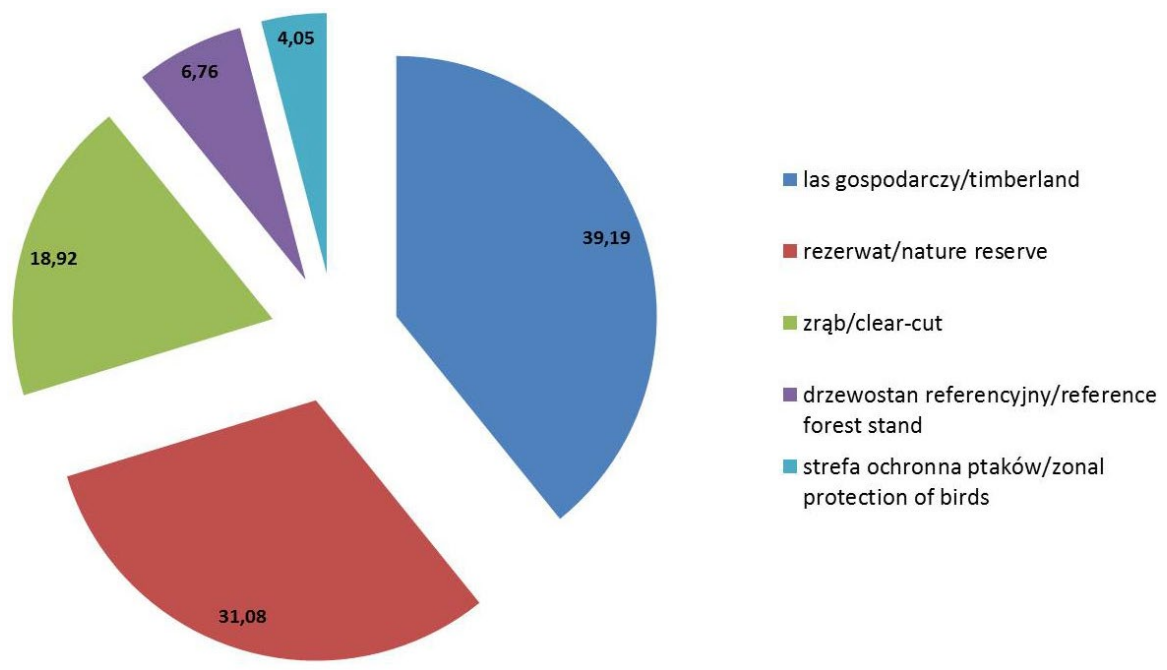

Ryc. 3. Występowanie Cucujus cinnaberinus według sposobu zarządzania lasem w Puszczy Knyszyńskiej

Fig. 3. Occurrence of Cucujus cinnaberinus in the Knyszyńska Forest, by forest management method

gdzie łącznie ze zrębami udział zasiedlonych drzew wynosił 58\% (Ryc. 3). Należy odnotować, że stwierdzono dwa drzewa zasiedlone przez C. cinnaberinus w drzewostanach porolnych, stanowiących wąskie zalesione pasy wśród pól uprawnych.

Boros schneideri został stwierdzony na 10 drzewach. Zazwyczaj odnajdywano pojedyncze larwy, rzadko po dwie na drzewie. Najczęściej notowany był na Pinus sylvestris (5 drzew), również na Alnus glutinosa (3 drzewa) i Picea abies (2 drzewa). Owady występowały na 7 drzewach w zwartym drzewostanie. Pozostałe 3 drzewa znajdowały się na zrębach: 2 w kępie ekologicznej i 1 jako pojedyncze drzewo biocenotyczne (dziuplaste) na zrębie. Wszystkie stwierdzenia dotyczyły drzewostanów gospodarczych.

Podczas prowadzonych obserwacji stwierdzono również obecność następujących rzadkich gatunków saproksylicznych, występujących na zamarłych drzewach:

Platylomalus complanatus (Panzer, 1797) - Histeridae

W Polsce bardzo rzadko spotykany (MAZUR 1981). Jest zoofagiem rozwijającym się w nasłonecznionych siedliskach. Spośród drzew preferuje Populus sp. (szczególnie P. tremula) i Fagus sylvatica oraz w mniejszym stopniu Quercus sp., Betula sp. i Salix sp. (Bouget i in. 2019). Występuje przeważnie pod zmurszałą korą martwych, stojących lub powalonych drzew (BURAKOwSKI i in. 1978). Jest uznawany za relikt lasów pierwotnych (ECKELT i in. 2017).

Stwierdzony w rezerwacie Budzisk, liczne okazy pod korą zamarłych, powalonych Populus tremula. Gatunek nowy dla Puszczy Knyszyńskiej.

\section{Ampedus elegantulus (Schönherr, 1817) - Elateridae}

W Polsce jest gatunkiem rzadko spotykanym, występującym w dobrze zachowanych kompleksach leśnych. Owady dorosłe z powodu skrytego sposobu życia są na ogół rzadko znajdowane (BURAKOwsKI i in. 1985). Jest zoofagiem żyjącym w wilgotnych siedliskach. Rozwija się na wielu gatunkach drzew iglastych i liściastych, głównie na Abies alba, Salix sp. i Populus sp. oraz rzadziej na Betula sp., Fagus sylvatica, 
Picea abies, Pinus sylvestris i Quercus sp. (BougET i in. 2019). Jest uznawany za relikt lasów pierwotnych (ECKELT i in. 2017).

Stwierdzony w rezerwacie Budzisk, na zamarłej Populus tremula. Gatunek nowy dla Puszczy Knyszyńskiej.

Diacanthous undulatus (De Geer, 1774) - Elateridae

W Polsce jest wykazywany stosunkowo rzadko, głównie w południowej części kraju. Z obszarów niżowych jest znany z Pojezierza Mazurskiego i z Puszczy Białowieskiej (BuRAKOwski i in. 1985). Zasiedla drzewa liściaste i iglaste, zwłaszcza Picea abies.

Stwierdzony w rezerwacie Budzisk - wylęgłe z poczwarek młode imagines pod korą Picea abies. Gatunek nowy dla Puszczy Knyszyńskiej.

\section{Otho sphondyloides (E.F. Germar, 1818) - Eucnemidae}

W Polsce znany wyłącznie z Puszczy Białowieskiej, okolic Kuźnicy Białostockiej na Podlasiu i Wereszyna na Wyżynie Lubelskiej (HILSZCZAŃSKI i in. 2015). Zamieszkuje biotopy leśne, mało zmienione wskutek gospodarki człowieka. Larwa żyje w wilgotnym, martwym, biało butwiejącym, ale jeszcze twardym drewnie grubych gałęzi, kłód leżących na ziemi oraz stojących pni i złomów. Jako drzewa żywicielskie podawano Carpinus betulus, Populus sp. i Quercus sp. (BURAKOwsKi i in. 1985). Jest uznawany za relikt lasów pierwotnych (ECKELT i in. 2017).

Stwierdzony w rezerwacie Budzisk, na martwych Populus tremula. Gatunek nowy dla Puszczy Knyszyńskiej.

\section{Xylophilus testaceus (Herbst, 1806) - Eucnemidae}

W Polsce znany zaledwie z kilku stanowisk (BURAKOWSKI i in. 1985). Jest saproksylofagiem, żyjącym w wilgotnych, ale widnych siedliskach. Związany jest głównie z Salix sp. i Populus sp. (Bouget i in. 2019). Rozwija się w wilgotnym, miękkim, brunatno butwiejącym drewnie (BURAKOwSKI i in. 1985).

Stwierdzony w rezerwacie Budzisk, na martwych Populus tremula. Gatunek nowy dla Puszczy Knyszyńskiej.

\section{Peltis grossa (Linnaeus, 1758) - Trogossitidae}

W Polsce notowany głównie w południowej i północno-wschodniej części kraju, na ogół rzadko znajdowany. Występuje przede wszystkim w lasach niezagospodarowanych, gdzie pnie martwych, grubych drzew nie są usuwane z lasu. Drzewami żywicielskimi dla larw są głównie Picea abies i Abies alba (BuRAKOWSKI i in. 1986c). Jest uznawany za relikt lasów pierwotnych (ECKELT i in. 2017).

Stwierdzony w rezerwacie Budzisk, pod korą Picea abies. Gatunek nowy dla Puszczy Knyszyńskiej.

\section{Thymalus limbatus (Fabricius, 1787) - Trogossitidae}

W Polsce znany z nielicznych stanowisk, głównie z południowej części kraju. Występuje w zmurszałym i przerośniętym grzybnią drewnie, pod obluźnioną korą, w hubach i na ich powierzchni. Zarówno larwy, jak i postacie dojrzałe żerują na grzybni i na owocnikach hub porastających drzewa iglaste i liściaste (BURAKOWSKI i in. 1986c).

Stwierdzony w rezerwacie Budzisk, pod korą Populus tremula i Picea abies. Gatunek był wcześniej stwierdzany w Puszczy Knyszyńskiej (Plewa i in. 2014).

\section{Ipidia binotata (E. Reitter, 1875) - Nitidulidae}

W Polsce rzadko spotykany, notowany na nielicznych stanowiskach na terenach nizinnych i górzystych. Występuje pod korą drzew iglastych, gdzie prowadzi drapieżny tryb życia, polując na larwy owadów (BURAKOWSKI i in. 1986a).

Stwierdzony w pobliżu miejscowości Horodnianka pod korą martwej Pinus sylvestris. Gatunek nowy dla Puszczy Knyszyńskiej. 


\section{Dendrophagus crenatus (G. Paykull, 1799) - Silvanidae}

W Polsce chrząszcz należy do rzadkości, notowany tylko z czterech krain. Żyje pod odstającą, mniej lub bardziej przerośniętą grzybnią i zmurszałą korą drzew iglastych, bardzo rzadko spotykany na drzewach liściastych. Występuje czasami na drzewach uprzednio uszkodzonych pożarem (BURAKOWSKI i in. 1986a).

Stwierdzony pod korą martwej Pinus sylvestris w okolicach rezerwatu Las Cieliczański na siedlisku boru mieszanego bagiennego - las referencyjny. Wiek sosen, na których stwierdzono gatunek to około 90 lat. Gatunek był wcześniej stwierdzany w Puszczy Knyszyńskiej na kilku stanowiskach (PLEwA i in. 2014).

\section{Leiestes seminiger (Gyllenhal, 1808) - Endomychidae}

W Polsce odnotowano go zaledwie na kilku stanowiskach. Związany jest z drzewami liściastymi, poławiano go m.in. na Populus tremula oraz na grubych, zmurszałych pniach i pniakach Betula sp. porośniętych owocnikami Piptoporus oraz Fomes (BURAKOwSKI i in. 1986b). Jest uznawany za relikt lasów pierwotnych (ECKELT i in. 2017).

Stwierdzony w rezerwacie Budzisk na owocnikach Fomes fomentarius porastających zamarłą Betula pendula oraz w drzewostanie referencyjnym w Nadleśnictwie Krynki na siedlisku lasu mieszanego wilgotnego. Gatunek był wcześniej stwierdzany w Puszczy Knyszyńskiej (Plewa i in. 2014).

Bothrideres bipunctatus (Gmelin, 1790) - Bothrideridae

W Polsce jest chrząszczem rzadko i sporadycznie spotykanym, znanym z nielicznych stanowisk w pięciu krainach (BURAKOwSKI i in. 1986b). Jest zoofagiem, którego drapieżne larwy żerują na larwach chrząszczy z rodzin: Cerambycidae, Ptinidae, Bostrychidae i Curculionidae, żyjącym w wilgotnych i zacienionych siedliskach (Bouget i in. 2019). Spotyka się go w starych drzewach.

Stwierdzony w pobliżu miejscowości Horodnianka w martwej Alnus glutinosa (razem z Boros schneideri) w drzewostanie olszowym na siedlisku olsu, w wieku ponad 90 lat. Jest to drzewostan referencyjny. Gatunek nowy dla Puszczy Knyszyńskiej.

\section{Phytobaenus amabilis (R.F. Sahlberg, 1834) - Aderidae}

W Polsce chrząszcz bardzo rzadki, znany tylko z sześciu krain, przy czym współcześnie stwierdzony wyłącznie w Puszczy Białowieskiej (KuBISZ i in. 2014). Biologia gatunku jest słabo poznana; osobniki poławiano na drzewach liściastych, pod odstającą korą starych drzew, w których prawdopodobnie odbywają rozwój w zmurszałym drewnie (BURAKOwSKI i in. 1987).

Stwierdzony w rezerwacie Budzisk, pod korą zamarłych, powalonych Populus tremula. Gatunek nowy dla Puszczy Knyszyńskiej.

\section{Phryganophilus auritus (Motschulsky, 1845) - Melandryidae}

W Polsce odnotowany był tylko na kilkunastu stanowiskach. Larwy żerują w wilgotnym, przerośniętym grzybnią drewnie gałęzi, również leżących na ziemi, w miejscach zacienionych. Jako materiał żywicielski podawano drewno Fagus sylvatica, Carpinus betulus i Quercus sp. (BURAKOWSKI i in. 1987). Jest uznawany za relikt lasów pierwotnych (ECKELT i in. 2017).

Stwierdzony w rezerwacie Budzisk, na pniu zamarłej Populus tremula. Gatunek nowy dla Puszczy Knyszyńskiej.

\section{Neomida haemorrhoidalis (Fabricius, 1787) - Tenebrionidae}

W Polsce znany z nielicznych stanowisk (BURAKOwsKi i in. 1987). Żyje w starych owocnikach grzybów, zwłaszcza z rodzajów Fomes, Ganoderma, Piptoporus i Trametes, występujących na drewnie drzew liściastych, przeważnie na Populus sp., Betula sp., Quercus sp., Alnus sp. i Fagus sylvatica (BougEt i in. 2019).

Stwierdzony w rezerwacie Budzisk na owocnikach Fomes fomentarius, porastających zamarłą Betula pendula. Gatunek był wcześniej stwierdzany w Puszczy Knyszyńskiej (Iwan i in. 2012). 
Platydema dejeanii (F. Castelnau et A. Brullé, 1831) - Tenebrionidae

W Polsce chrząszcz należy do wielkich rzadkości, znany u nas tylko z pięciu krain. Występuje w rozkładającym się drewnie pni i gałęzi drzew liściastych pod odstającą korą, w owocnikach grzybów oraz wśród mchów rosnących na pniach i pieńkach (BURAKOWSKI i in. 1987). Jest uznawany za relikt lasów pierwotnych (ECKELT i in. 2017).

Stwierdzony w rezerwacie Budzisk na owocnikach Fomes fomentarius porastających zamarłą Betula pendula. Gatunek nowy dla Puszczy Knyszyńskiej.

\section{DYSKUSJA}

Jednym z głównych zagrożeń dla bioróżnorodności lasów poddanych presji gospodarczej jest fragmentacja i izolacja obszarów leśnych (ASSMANN 1999; DESENDER 2005). Wiele gatunków reliktowych, szczególnie związanych z rozkładającym się drewnem, ma ograniczoną zdolność kolonizowania nowych obszarów, co jest szczególnie istotne w przypadku wystąpienia zaburzenia, niezależnie czy naturalnego, czy spowodowanego działalnością człowieka (ASSMANN 1999; DESENDER 2005). W przypadku gatunków owadów saproksylicznych, kluczowym elementem środowiska, niezbędnym do ich występowania, jest obecność zamarłych i zamierających drzew w różnych fazach rozkładu (EcKELT i in. 2017). Bardzo duża specyfika wymagań pokarmowych oraz zasiedlanie często bardzo niewielkich mikrośrodowisk sprawia, że chrząszcze saproksyliczne są grupą niezwykle wrażliwą na zmiany stanu ekosystemu leśnego (BYK i in. 2013). Z tego względu najistotniejsze znaczenie ma obecność różnorodnego substratu, właściwego do zasiedlenia przez poszczególne gatunki. W lasach niezbędne jest więc występowanie drzew o różnym stopniu rozkładu, stojących, leżących czy dziuplastych o różnych rozmiarach (HILSZCZAŃsKI i in. 2011). Dobre warunki do rozwoju tych gatunków można spotkać w obszarach objętych ochroną, gdzie pozostaje większość zamierających i martwych drzew, a więc w parkach narodowych i niektórych rezerwatach leśnych, zapewniających ciąłość podaży odpowiednich mikrosiedlisk. Większość lasów w Polsce stanowią jednak drzewostany gospodarcze, w których zasobność martwych drzew jest zdecydowanie mniejsza. Warto jednak podkreślić, iż gospodarka leśna nie wyklucza możliwości ochrony saproksylobiontów, pod warunkiem, że jest prowadzona na racjonalnych zasadach.

Zasady obowiązujące w Lasach Państwowych, zapoczątkowane formalnie zarządzeniem dyrektora generalnego Lasów Państwowych nr 11A z 1996 r. i obecnie przeniesione do aktualnych instrukcji i zasad branżowych, wprowadzają szereg działań umożliwiających stałą podaż zamierających drzew w lesie. Zgodnie z InstrukcJą Ochrony LASU (2012), aby kształtować możliwie dużą złożoność ekosystemów leśnych w ramach prowadzonej gospodarki leśnej, należy pozostawiać na stałe w drzewostanach drzewa biocenotyczne (dokładna definicja znajduje się w INSTRUKCJI OCHRONY LASU 2012, w części I rozdział 3.2) do ich naturalnej śmierci i rozkładu. Dodatkowo zaleca się pozostawiać w lesie posusz jałowy, który ma stanowić zasób martwych drzew. Ponadto nadleśnictwa realizują inne działania na rzecz ochrony różnorodności biologicznej, takie jak wyznaczanie wydzieleń referencyjnych, gdzie nie prowadzi się zabiegów związanych z pozyskaniem drewna. Ważnym elementem w krajobrazie lasu gospodarczego jest pozostawianie kęp ekologicznych, które 
- zgodnie z obowiązującym Rozporządzeniem w sprawie wymagań dobrej praktyki w zakresie gospodarki leśnej (ROZPORZACZENIE 2017) - powinny być na wszystkich rębniach, gdzie następuje uprzątnięcie drzewostanu cięciami zupełnymi. Dopiero stosując się do powyższych zasad można mówić o zrównoważonej gospodarce leśnej, w zakresie której poza celami ekonomicznymi pod uwagę bierze się również uwarunkowania ochrony przyrody.

$\mathrm{Z}$ analizy danych zawartych w obowiązujących planach urządzenia lasu dla Puszczy Knyszyńskiej można wywnioskować, że mamy do czynienia z kompleksem leśnym o stosunkowo dużej zasobności drewna w różnych fazach rozkładu, znacznie przekraczającej średnią krajową. W zależności od analizowanego obrębu leśnego są to ilości na poziomie pomiędzy 8,16 a $17,77 \mathrm{~m}^{3} /$ ha. Wyjątek stanowi obręb Katrynka, znacząco odbiegający od pozostałych obrębów puszczańskich oraz dwa obręby nadleśnictwa Żednia, które tylko częściowo obejmują obszar Puszczy. Z pewnością taka sytuacja w Puszczy związana jest z obecnością licznych rezerwatów przyrody oraz terenów podmokłych i bagiennych, gdzie gospodarowanie jest utrudnione. Niemniej, należy również zaznaczyć, że obraz ten jest efektem wprowadzonych regulacji, umożliwiających pozostawianie posuszu jałowego.

W lasach gospodarczych nie należy oczekiwać znacznych ilości substratu dogodnego do zasiedlania przez rzadkie gatunki saproksylobiontów z różnych przyczyn. Przede wszystkim konieczność utrzymywania stanu sanitarnego lasu sprawia, że w znacznej mierze usuwane są drzewa zasiedlone przez gatunki powodujące ich zamieranie (PAPIS \& MoKRZYCKI 2015). Dodatkowo nie bez znaczenia jest potrzeba zapewnienia bezpieczeństwa osób przebywających w lesie, zarówno turystów, jak również pracowników wykonujących prace gospodarcze. Stąd pozostawienie większej ilości martwych drzew może być problematyczne. Wydaje się jednak, że ilość mikrośrodowisk związanych z zamarłymi drzewami i rozkładającym się drewnem w Puszczy Knyszyńskiej w wielu miejscach jest wystarczająca dla ochrony różnorodności biologicznej saproksylobiontów. Według CzEREPKO (2008) ilość martwych drzew i substratu w fazach dekompozycji przekraczająca $10 \mathrm{~m}^{3} /$ ha zapewnia właściwe warunki do rozwoju owadów saproksylicznych. Do tego istotniejsza od ciągłego zwiększania depozytu jest jakość dostępnych mikrosiedlisk, a więc przede wszystkim rozmiar martwych drzew i stała obecność wszystkich faz rozkładu drewna (HILSZCZAŃSKI i in. 2011).

O dobrych warunkach dla występowania owadów saproksylicznych w całym kompleksie leśnym Puszczy Knyszyńskiej świadczy obecność Cucujus cinnaberinus i Boros schneideri oraz wielu gatunków uznanych za relikty lasów pierwotnych. Oba wymienione powyżej gatunki uznawane są za bardzo rzadkie i wskazują najlepiej zachowane obszary leśne (KuBISZ 2004; BLAŽYTE-ČEREŠKIENE \& KARALIUS 2012; BuCHHOLZ i in. 2013; GUTOWSKI i in. 2014; GUTOWSKI 2015). Zgodnie z założeniami przyjmowanymi jeszcze kilkanaście lat temu, oba gatunki powinny występować jedynie w parkach narodowych i rezerwatach przyrody na obszarach puszczańskich (KuBISZ 2004). Z prowadzonych obserwacji w Puszczy Knyszyńskiej wynika bezsprzecznie, że gatunki te z powodzeniem mogą występować w lasach zagospodarowanych. Opracowywane modele występowania np. C. cinnaberinus oparte o niedostateczne dane, wykluczają lasy gospodarcze np. Puszczę Knyszyńską jako miejsca dogodnych siedlisk dla tego gatunku (BEŁCIK i in. 2019). Prezentowane badania wskazują jednak, że populacja gatunku jest tam liczna i stabilna. W dość 
licznych publikacjach z ostatnich lat znajdujemy doniesienia, że gatunki wcześniej uważane za puszczańskie, spotykane są nie tylko na takich obszarach, w tym objętych ochroną ścisłą. Na Litwie B. schneideri notowany jest na pojedynczych drzewach na zrębach oraz w stosunkowo młodych sztucznych drzewostanach sosnowych (KARALIUS i in. 2006; BLAŽYTE-ČEREŠKIENE \& KARALIUS 2010, 2012). Oba analizowane w niniejszej pracy gatunki są podawane z obszaru nadleśnictw Pogórza Przemyskiego i Bieszczadów, gdzie prowadzona jest gospodarka leśna (BuchHolz i in. 2012, 2013). Z kolei C. cinnaberinus coraz częściej notowany jest $\mathrm{z}$ terenów zagospodarowanych, a nawet zurbanizowanych. PRZEwOŹNY (2014) donosi o obserwacji imago tego gatunku w zabudowanym obszarze Poznania przypuszczając, że populacja może bytować w zaroślach nad Wartą lub w parku Maltańskim. Cucujus cinnaberinus notowany jest na Pogórzu Śląskim ze stanowisk zarówno objętych ochroną rezerwatową, jak i z lasów gospodarczych o różnej intensywności użytkowania (DORDA \& FIEDOR 2019) oraz z drzewostanów gospodarczych w okolicy Dębicy (TRZECIAK 2011). Znane są również stanowiska $C$. cinnaberinus w starych plantacjach topolowych w Czechach (HoRAK i in. 2010), czy w niewielkim lasku topolowym w Radomiu, którego pochodzenie jest bez wątpienia sztuczne (MıŁKOwSKI 2012). Nowe stanowiska tego gatunku stwierdzono również w południowo-zachodniej Polsce, gdzie znajdowano go w niewielkich kompleksach leśnych, otoczonych terenami otwartymi i w zaroślach wierzbowo-topolowych w dolinach rzek (SMOLIs i in. 2012).

Wspólną cechą wszystkich opisanych powyżej stanowisk jest obecność martwych i zamierających drzew różnych gatunków, choć nie wszędzie są to ilości określane jako duże. Ważna jest dostępność martwych drzew w różnym stopniu rozkładu, natomiast skala przekształcenia ekosystemu leśnego i ciągłość lasu na danym obszarze wydaje się mieć drugorzędne znaczenie (SMOLIS i in. 2012). Również TRzeCiAK (2011) przypuszcza, że zabiegi gospodarcze, takie jak trzebieże czy cięcia rębne, mają mniejsze znaczenie pod warunkiem zapewnienia obecności martwych drzew w różnym stopniu rozkładu.

Tak też jest w Puszczy Knyszyńskiej, gdzie saproksyliczne chrząszcze były notowane nie tylko w lasach objętych reżimami ochronnymi, ale również w drzewostanach gospodarczych. Szczególnie często spotykany był Cucujus cinnaberinus, nawet tam, gdzie $\mathrm{w}$ drzewostanie znajdowano zaledwie pojedyncze martwe drzewa. Istotne zatem jest rozpatrywanie całego kompleksu leśnego jako przestrzennego układu o zróżnicowanym rozkładzie mikrosiedlisk. Z pewnością rezerwaty przyrody oraz wydzielenia referencyjne, które są ze swej natury bogate w zamarłe drzewa, będą stanowiły bardzo istotne obszary rozwoju tych owadów i tu należy się spodziewać szczególnie licznej populacji. Obszary takie można uznać za refugia tych gatunków dla otaczających je obszarów poddanych użytkowaniu gospodarczemu. Nieco inaczej sytuacja wygląda w lesie zagospodarowanym, gdzie występuje znacznie mniej rozkładającego się drewna, jednak ważne jest, aby przynajmniej pojedyncze zamierające drzewa różnych gatunków były pozostawiane do naturalnego rozkładu. W badanym obiekcie nietrudno napotkać pojedyncze martwe drzewa. Bardzo często były one zasiedlone przez omawiane rzadkie gatunki saproksylobiontów.

Na podstawie przeprowadzonych obserwacji w Puszczy Knyszyńskiej wskazać należy ważny element krajobrazu, jakim są kępy ekologiczne na zrębach. Pozostawiane fragmenty starego drzewostanu są istotnym rezerwuarem zamierających i martwych drzew. Zasady 
przyjęte w Lasach Państwowych generalnie nie pozwalają zagospodarowywać drzew z kęp w przypadku ich zamarcia lub wywrócenia się. Pozwala to na rozmieszczenie dość regularnie w kompleksie leśnym warunków właściwych do zasiedlenia przez gatunki saproksyliczne. W przypadku kęp, w których były martwe drzewa leżące lub stojące, stwierdzano larwy obu gatunków. Potwierdza to obserwacje ze Szwajcarii z drzewostanów dębowo-bukowych, gdzie wykazano, że wyspy starodrzewu sprzyjają utrzymywaniu się populacji owadów saproksylicznych w mozaikowym krajobrazie lasów zagospodarowanych (BARBALAT 2012). Ważne pytanie, na które należy znaleźć odpowiedź, dotyczy trwałości mikrosiedlisk odpowiednich dla gatunków saproksylicznych w biogrupach. Drzewa w kępach ekologicznych z reguły są narażone na silne nagrzewanie i istnieje ryzyko zbyt szybkiego przesychania warstwy podkorowej. W przypadku Boros schneideri prawdopodobnie nie stanowi to dużego problemu, skoro spotyka się larwy tego gatunku na pojedynczych drzewach w Puszczy Augustowskiej (dane własne niepublikowane), Knyszyńskiej oraz na Litwie (BLAŽYTE-ČEREŠKIENE \& KARALIUS 2010, 2012). W przypadku Cucujus cinnaberinus, który ma dłuższy okres rozwoju larwy, może to stanowić pewne ograniczenie. Biorąc pod uwagę, że niektórzy autorzy podają, iż jest to gatunek lubiący przerzedzone drzewostany, z większym dostępem światła (HORAK i in. 2010; JAwORSKI i in. 2019), warunki na kępach mogą okazać się wystarczające. To zagadnienie wymaga jednak dalszych badań, również pod kątem określenia optymalnej wielkości kęp.

Coraz szersza wiedza na temat występowania obu gatunków, w tym prezentowane wyniki, sugerują, że mogą one z powodzeniem występować w kompleksach leśnych, gdzie prowadzona jest racjonalna gospodarka leśna. Oznacza to, że w granicach kompleksu leśnego znajdują się obszary objęte prawną formą ochrony, wykluczającą gospodarowanie, takie jak rezerwaty przyrody oraz miejsca nieużytkowane, tj. tereny referencyjne czy kępy ekologiczne, w miarę równomiernie rozmieszczone w przestrzeni. Dodatkowo w lesie gospodarczym nie muszą być usuwane wszystkie zamierające drzewa, dzięki czemu owady mają możliwość zasiedlania i rozwoju w pojedynczych martwych drzewach rozmieszczonych w całym kompleksie. To wszystko powoduje, że realizując zasady zrównoważonej gospodarki leśnej można skutecznie ochronić populację owadów saproksylicznych.

Ważnym zagrożeniem dla stanowisk rzadkich gatunków saproksylicznych jest planowana budowa drogi ekspresowej nr 19 przez obszar Puszczy Knyszyńskiej (wariant nr 5) wytyczony przez Wasilków, Czarną Białostocką i Straż (Generalna DyreKcua 2019). $\mathrm{Na}$ trasie przebiegu planowanej inwestycji znajduje się najliczniejsze obecnie stanowisko Boros schenideri, kilka stanowisk Cucujus cinnaberinus oraz jedyne Boros bipunctatus. Dotychczasowy planowany przebieg tego odcinka drogi krajowej S19 omijał Puszczę. Inwestycja ta spowoduje istotną fragmentację Puszczy Knyszyńskiej, będącej obszarem Natura 2000. W pofragmentowanym środowisku leśnym, poprzecinanym bezdrzewnymi pasami różnej szerokości, populacje gatunków saproksylicznych zostaną odizolowane. Warto tu podkreślić, iż nie wszystkie rzadkie gatunki saproksylobiontów są dobrymi lotnikami - część gatunków ma całkowicie uwstecznione skrzydła drugiej pary. Dodatkowo w wielu przypadkach, szczególnie gatunków cieniolubnych, może następować zawężenie areałów występowania do wnętrza wysp powstałych po fragmentacji, z różnym natężeniem negatywnego wpływu efektu krawędzi (SŁAWSKI 2008). 
Przedstawione wyniki nie określają zagęszczenia populacji czy liczebności na poszczególnych stanowiskach. Nie analizowano także preferencji obu gatunków w stosunku do konkretnych drzew czy typów siedliskowych lasu. Stanowią one wstępne rozpoznanie występowania Cucujus cinnaberinus i Boros schneideri w Puszczy Knyszyńskiej i powinny stanowić przyczynek do większych badań i głębszych analiz. Szersze analizy wymagają bardziej szczegółowych badań, zaplanowanych na wiele lat. Należałoby oczekiwać w przyszłości takich badań w tak cennym kompleksie leśnym jakim jest Puszcza Knyszyńska.

\section{WNIOSKI}

1. Puszcza Knyszyńska jest się ważną ostoją rzadkich gatunków chrząszczy saproksylicznych.

2. Zarówno Cucujus cinnaberinus jak i Boros schneideri mogą występować w lasach objętych zrównoważoną gospodarką leśną, pod warunkiem zapewnienia odpowiedniej ilości mikrośrodowisk - zmarłych drzew we wszystkich fazach rozkładu.

3. O dobrym stanie ochrony Puszczy Knyszyńskiej świadczy występowanie, poza C. cinnaberinus i B. schneideri, całego kompleksu cennych, reliktowych saproksylobiontów.

4. Cennym elementem w krajobrazie zagospodarowanego lasu są kępy ekologiczne oraz pozostawione pojedyncze martwe drzewa, gdyż stanowią bardzo ważne mikrosiedlisko, niezbędne dla rzadkich gatunków owadów.

5. Wiedza o rozmieszczeniu i preferencjach siedliskowych C. cinnaberinus oraz B. schneideri w Puszczy Knyszyńskiej jest nadal niewystarczająca i wymaga dalszych badań.

Podziękowania. Badania przeprowadzono za zgodą na odstępstwa od zakazów obowiązujących w stosunku do gatunków objętych ochroną wydaną przez Regionalnego Dyrektora Ochrony Środowiska w Białymstoku.

\section{LITERATURA}

AsSMANN T. 1999. The ground beetle fauna of ancient and recent woodlands in the lowlands of northwest Germany (Coleoptera, Carabidae). - Biodiversity and Conservation 8: 1499-1517.

BARBALAT S. 2012. Measures favouring saproxylic beetles in a forest reserve. - Schweizerische Zeitschrift fur Forstwesen 163(2): 43-48.

BęciK M., GoczaŁ J. \& Ciach M. 2019. Large-scale habitat model reveals a key role of large trees and protected areas in the metapopulation survival of the saproxylic specialist Cucujus cinnaberinus. - Biodiversity and Conservation 28(14): 3851-3871.

BiURo URZĄDZANIA LASU i GeOdEZJ LEŚNEJ. 2015. Wielkoobszarowa inwentaryzacja stanu lasu. Wyniki II cyklu (lata 2010-2014). s. 433. Instytut Badawczy Leśnictwa, Sękocin Stary.

BLAŽYTE-ČEREŠKIENE L. \& KARALIUS V. 2010. New records of Boros schneideri (Panzer, 1796) (Coleoptera, Boridae) in Lithuania in 2007. - New and rare for Lithuania insects species 22: 74-80.

BLAŽYTE-ČEREŠKIENE L. \& KARALIUS V. 2012. Habitat requirements of the endangered beetle Boros schneideri (Panzer, 1796) (Coleoptera; Boroidae). - Insect Conservation and Diversity 5(3): 186-191. 
Bouget Ch., Brustel H., Noblecourt T. \& Zagatti P. 2019. The saproxylic beetles of France: Illustrated Ecological Catalogue. s. 738. Muséum National d'Histoire Naturelle, Paryż.

BuchHolz L. 2012. Zgniotek cynobrowy Cucujus cinnaberinus. - W: M. MaKomaska-Juchiewicz \& P. BARAN (red.), Monitoring gatunków zwierząt. Przewodnik metodyczny. 2, s. 419-446. Główny Inspektorat Ochrony Środowiska, Warszawa.

Buchholz L., Olbrycht T. \& Melke A. 2012. Występowanie Boros schneideri (Panzer, 1796) (Coleoptera: Boridae) w południowo-wschodniej Polsce. - Wiadomości Entomologiczne 31(3): 207-209.

Buchholz L., Kuberski Ł., Michalski R., Melke A. \& Olbrycht T. 2013. Chrząszcze (Coleoptera) z załącznika II Dyrektywy Siedliskowej na obszarze projektowanego Turnickiego Parku Narodowego i w jego okolicach. - Roczniki Bieszczadzkie 21: 297-317.

Burakowski B., Mroczkowski M. \& Stefańska J. 1978. Chrząszcze - Coleoptera. Histeroidea i Staphylinoidea prócz Staphylinidae. - Katalog Fauny Polski 23(5): 1-356.

Burakowski B., Mroczkowski M. \& Stefańska J. 1985. Chrząszcze - Coleoptera. Buprestoidea, Elateroidea i Cantharoidea. - Katalog Fauny Polski 23(10): 1-401.

Burakowski B., Mroczkowski M. \& Stefańska J. 1986a. Chrząszcze - Coleoptera. Cucujoidea, część 1. - Katalog Fauny Polski 23(12): 1-266.

Burakowski B., Mroczkowski M. \& Stefańska J. 1986b. Chrząszcze - Coleoptera. Cucujoidea, część 2. - Katalog Fauny Polski 23(13): 1-278.

Burakowski B., Mroczkowski M. \& Stefańska J. 1986c. Chrząszcze - Coleoptera. Dermestoidea, Bostrichoidea, Cleroidea i Lymexyloidea. - Katalog Fauny Polski 23(11): 1-243.

Burakowski B., Mroczkowski M. \& Stefańska J. 1987. Chrząszcze - Coleoptera. Cucujoidea, część 3. - Katalog Fauny Polski 23(14): 1-309.

Byk A., Borowski J., Mazur S., Mokrzycki T. \& Rutkiewicz A. 2013. Waloryzacja lasów Leśnego Kompleksu Promocyjnego „Lasy Spalsko-Rogowskie” na podstawie struktury zgrupowań chrząszczy saproksylicznych. - Studia i Materiały Centrum Edukacji Przyrodniczo-Leśnej w Rogowie 35(2): 82-128.

Czerepko J. (red.). 2008. Stan różnorodności biologicznej lasów w Polsce na podstawie powierzchni obserwacyjnych monitoringu. Synteza wyników uzyskanych w ramach projektu BioSoil Forest Biodiversity. s. 135. Instytut Badawczy Leśnictwa, Sękocin Stary.

DESENDER K. 2005. Theory versus reality: a review on the ecological and population genetic effects of forest fragmentation on wild organisms, with an emphasis on ground beetles. - DIAS Reports 114: 49-72.

Dorda A. \& FIEDOR M. 2019. Występowanie zgniotka cynobrowego Cucujus cinnaberinus Scopoli 1763 (Coleoptera, Cucujidae) na Pogórzu Śląskim (Karpaty Zachodnie). - Przegląd Przyrodniczy 30(1): 98-104.

DYREKTYWA RADY 79/409/EWG z dnia 2 kwietnia 1979 r. w sprawie ochrony dzikiego ptactwa.

DYREKTYWA RADY 92/43/EWG z dnia 21 maja 1992 r. w sprawie ochrony siedlisk przyrodniczych oraz dzikiej fauny i flory.

Eckelt A., Müller J., Bense U., Brustel H., Bußler H., Chittaro Y., Cizek L., Frei A., Holzer E., Kadej M., Kahlen M., Köhler F., Möller G., Mühle H., Sanchez A., Schaffrath U., Schmidl J., Smolis A., Szallies A., Németh T., Wurst C., Thorn S., Christensen R. H. B. \& Seibold S. 2017. "Primeval forest relict beetles" of Central Europe: a set of 168 umbrella species for the protection of primeval forest remnants. - Journal of Insects Conservation 22: 15-28.

Generalna Dyrekcja Dróg Krajowych i Autostrad. 2019. https://www.gddkia.gov.pl (dostęp: 17.12.2019). 
GóRniak A. \& JEKATERynczuk-Rudczyk E. 1995. Stosunki wodne regionu Puszczy Knyszyńskiej. - W: A. Czerwiński (red.), Puszcza Knyszyńska, s. 49-71. Zespół Parków Krajobrazowych w Supraślu, Supraśl.

GuTOwski J. M. 2006. Saproksyliczne chrząszcze. - Kosmos 55(1): 53-73.

Gutowski J. M. 2015. Ponurek Schneidera Boros schneideri. - W: M. MAKomaSKA-JuchIEWICZ \& M. BonK (red.), Monitoring gatunków zwierząt. Przewodnik metodyczny. 4, s. 162-187. Główny Inspektorat Ochrony Środowiska, Warszawa.

Gutowski J. M., SućKo K., Zub K. \& Bohdan A. 2014. Habitat preferences of Boros schneideri (Panzer, 1796) (Coleoptera; Boroidae) in the natural tree-stands of the Białowieża forest. - Journal of Insect Science 14(276): 2019, DOI:10.1093/jisesa/ieu138.

HilszCZAŃSKi J., JawORSKI T. \& Plewa R. 2011. Dlaczego owady saproksyliczne „znikaja” z naszych lasów, czyli o wyższej wartości jakości martwego drewna nad jego ilością. - Studia i Materiały Centrum Edukacji Przyrodniczo-Leśnej w Rogowie 27(2): 200-206.

HilszCZAŃSKi J., Plewa R., JaWORSKI T. \& SIERPIŃSKi A. 2015. Microrhagus pyrenaeus Bonvouloir, 1872 - a false click beetle new for the fauna of Poland with faunistic and ecological data on Eucnemidae. - Spixiana 38(1): 77-84.

HoraK J., VAVRowa E. \& СНовот K. 2010. Habitat preferences influencing populations, distribution and conservation of the endangered saproxylic beetle Cucujus cinnaberinus (Coleoptera, Cucujidae) at the landscape level. - European Journal of Entomology 107: 81-88.

InstrukCua OChrony Lasu. 2012. Część I, III i IV. 1, s. 124. Centrum Informacyjne Lasów Państwowych, Warszawa.

Iwan D., Kubisz D. \& TyKarski P. 2012. Coleoptera Poloniae: Tenebrionoidea (Tenebrionidae, Boridae). Critical checklist, distribution in Poland and meta-analysis. s. 470. University of Warsaw - Faculty of Biology, Natura optima dux Foundation, Warszawa.

Jaworski T., Plewa R., Tarwacki G., SućKo K., Hilszczański J. \& Horak J. 2019. Ecologically similar saproxylic beetles depend on diversified deadwood resources: From habitat requirements to management implications. - Forest Ecology and Management 449: 117462.

Karalius V., Ferenca R., Uselis V., Jukoniene I. \& Sablevicius B. 2006. Findings of Boros schneideri (Panzer, 1796) in 2006. - New and rare for Lithuania insects species 17: 22-24.

KuBISZ D. 2004. Cucujus cinnaberinus (Scopoli, 1763). Zgniotek cynobrowy. - W: P. ADAMSKI, R. BARTEl, A. BereszyŃSKi, A. KePEl \& Z. WitKowsKi (red.), Gatunki zwierząt (z wyjątkiem ptaków). Poradniki ochrony siedlisk i gatunków Natura 2000 - poradnik metodyczny. 6, s. 88-90. Ministerstwo Środowiska, Warszawa.

Kubisz D., IwAn D. \& TYKarski P. 2014. Tenebrionoidea: Tetratomidae, Melandryidae, Ripiphoridae, Prostomidae, Oedemeridae, Mycteridae, Pythidae, Aderidae, Scraptiidae. Critical checklist, distribution in Poland and meta-analysis. Coleoptera Poloniae. 2, s. 470. University of Warsaw - Faculty of Biology, Natura optima dux Foundation, Warszawa.

MARCZAK D. 2016. Zgniotek cynobrowy Cucujus cinnaberinus w Kampinoskim Parku Narodowym i uwagi do jego monitoringu. - Studia i Materiały Centrum Edukacji Przyrodniczo-Leśnej w Rogowie 49A: 142-152.

MıŁKowsKi M. 2012. Zgniotek cynobrowy Cucujus cinnaberinus (Scopoli, 1763) (Coleoptera: Cucujidae) w Radomiu. - Kulon 17: 139-141.

Nieto A. \& AleXander K. N. A. 2010. European Red List of saproxylic beetles. s. 45. Publications Office of the European Union, Luxemburg. 
PAPIS M. \& MoKRZYCKI T. 2015. Chrząszcze saproksyliczne (Coleoptera) obszaru ochrony ścisłej Bukowa Góra w Roztoczańskim Parku Narodowym. - Leśne Prace Badawcze 76(3): 229-239.

Plewa R., Hilszczański J., Jaworski T. \& Sierpiński A. 2014. Nowe i rzadko spotykane chrząszcze (Coleoptera) saproksyliczne wschodniej Polski. - Wiadomości Entomologiczne 33(2): 85-96.

PrZewoźny M. 2014. Potwierdzenie występowania Cucujus cinnaberinus (Scopoli, 1763) w Poznaniu. - Wiadomości Entomologiczne 33(4): 286-287.

RoZPORZĄDZENIE Ministra Środowiska z dnia 16 grudnia 2016 r. w sprawie ochrony gatunkowej zwierząt (Dz. U. 2016 r., poz. 2183).

RozPORZĄDZENIE Ministra Środowiska z dnia 18 grudnia 2017 r. w sprawie wymagań dobrej praktyki w zakresie gospodarki leśnej (Dz. U. 2017 r., poz. 2408).

SŁAwSKI M. 2008. Wewnętrzna fragmentacja lasu i jej skutki przyrodnicze. - Studia i Materiały Centrum Edukacji Przyrodniczo-Leśnej w Rogowie 10(3): 55-60.

Smolis A., Kadej M., Gutowski J. M., Ruta R. \& Matraj M. 2012. Zgniotek cynobrowy Cucujus cinnaberinus (Insecta: Coleoptera: Cucujidae) - rozmieszczenie, ekologia i problemy ochrony oraz nowe stanowiska w Polsce południowo-zachodniej. - Chrońmy Przyrodę Ojczystą 68(5): 332-346.

SokoŁowski A. W. 1981. Projekt sieci rezerwatów w Puszczy Knyszyńskiej. - Parki Narodowe i Rezerwaty Przyrody 2(1): 45-72.

SokoŁowski A. W. 2006. Lasy Polski. s. 358. Centrum Informacyjne Lasów Państwowych, Warszawa.

TrzeciaK A. 2011. Występowanie Cucujus cinnaberinus (Scopoli 1763) (Coleoptera: Cucujidea) w okolicach Dębicy. - Wiadomości Entomologiczne 30: 185-186.

\section{SUMMARY}

In 2018 and 2019, saproxylic beetles were surveyed in the Knyszyńska Forest, an extensive forest complex in north-eastern Poland. The research was focused on two rare beetle species: Cucujus cinnaberinus and Boros schneideri. Previously only a few C. cinnaberinus habitats in the Knyszyńska Forest had been documented, and there was no record of B. schneideri in published sources describing the beetle fauna of the research site.

During the study, Cucujus cinnaberinus was found on 74 trees of various species. Scots pine (Pinus sylvestris) and poplar (Populus tremula) dominated the group of trees on which the beetles were found. Cucujus cinnaberinus was also present on oak (Quercus sp.), silver birch (Betula pendula), common maple (Acer platanoides), black alder (Alnus glutinosa), common ash (Fraxinus excelsior) and elm (Ulmus sp.) (Fig. 1). The majority of the stations were in sustainably managed forest. Cucujus cinnaberinus was also present on highly altered forest sites such as clearings within retention patches, and on solitary trees (Fig. 3).

The research documented ten new habitats of Boros schneideri where Scot pine (Pinus sylvestris) was the dominant tree. Black alder (Alnus glutinosa) and Norway spruce (Picea abies) were also present in the group of trees hosting the beetle. The sites where $B$. schneideri was documented were located entirely in sustainably managed forest, including retention patches and snags. Also found in this study were many other rare insect species not previously listed for the Knyszyńska Forest.

These findings suggest that sustainably managed forest may offer a suitable refuge for rare saproxylic insects. In such a forest complex, various forms of nature conservation should be applied, including nature reserves, sites of limited management, single dead trees, and retention patches left in harvested clearings. The present data add to our knowledge of rare saproxylic beetles, especially those inhabiting sustainably managed forests.

Wptynęto: 14.02.2020 r.; przyjęto do druku: 26.02.2020 r. 